NOTICE: this is the author's version of a work that was accepted for publication in the Journal of Unconventional Oil and Gas Resources. Changes resulting from the publishing process, such as peer review, editing, corrections, structural formatting, and other quality control mechanisms may not be reflected in this document. Changes may have been made to this work since it was submitted for publication. A definitive version was subsequently published in the Journal of Unconventional Oil and Gas Resources, Vol.7, (2014). DOI: 10.1016/j.juogr.2014.01.001 


\title{
Significance of Compressional Tectonic on Pore Pressure Distribution in Perth Basin
}

\author{
Abualksim Ahmad, Reza Rezaee \& Vamegh Rasouli \\ Department of Petroleum Engineering, Curtin University, Perth, Western Australia
}

\begin{abstract}
The Perth Basin is one of the major tectonic structures along the western continental margin of Australia and was initially formed through the rifting and break-up of the Indian and Australian plates. The severe tectonic movements accompanied and occurred after the break-up are responsible for the most structural elements and for the distribution of pore pressure in the basin.

Investigations on the well log data from the Perth Basin have identified shale intervals which are characterised as overpressured in some parts of the basin, whereas similar shale intervals found to be normally pressured in other parts of the basin. The phenomena of overpressure have frequently been reported while drilling the same intervals. Based on this research, sections with overpressure were observed in the majority of the wells in the basal section of the Kockatea shale where there were less tectonic activities have been recorded. Normal pore pressure was observed in shallower wells in the Kockatea shales which were located within uplifted sections that were more tectonically active areas.

Based on the results of this research, the pore pressure distribution in the Kockatea Shale varied significantly from one part of the Perth basin to another as a result of compressive tectonic stress. Compressional tectonic activities either induced fracturing in shallower localities (e.g. Beagle Ridge, Cadda Terrace and the adjacent terraces) or removed part of the Kockatea Shale as a result of faulting resulting in overpressures being released. Regions with less intensity of the tectonic activities showed an increase in pressure gradients as approaching away from the centre of uplift.
\end{abstract}




\section{Introduction}

Several sedimentary basins around the world display some sort of abnormal pore pressure, particularly abnormal high-pressure (overpressure). The overpressure phenomenon is commonly observed in low permeability zones such as shale formations as they tend to retain overpressures compared to other kind of rock types (Osborne and Swarbrick 1997).

No research has been done to assess pore pressure in shale formations in the Perth Basin. The primary purpose of this study is to estimate the pore pressure and evaluate its distribution in the Perth Basin using well log data. This study is part of a bigger project that evaluates shale gas potential intervals in the Perth and Canning basins. The relationship between pore pressure and the tectonically structural events was also studied in this research, and the results were analysed and presented here. This work will inform a better understanding of the overpressure and tectonics events in the Perth Basin, and in turn, a better understanding and an assessment of the shale candidate formations. Shale's pore pressure is important particularly when studied in conjunction with other shale characteristics such as thermal maturity and total organic contents (TOC) which may be used for the identification of the shale gas sweet spots.

\section{Structure and geological setting}

The Perth Basin is an elongated north-south extent in the southwest of Western Australia. The basin covers approximately $100,000 \mathrm{~km}^{2}$ along the west coast of Australia and extends between Geraldton and Augusta. The basin contains sedimentary succession that varies from Silurian to Pleistocene (Mory, Haig et al. 2005). To the north, the basin is bounded by the Northampton block and the eastern margin of the basin is defined by Darling fault. Half of the basin is located onshore and extends to the west offshore to the edge of the continental shelf (lasky and Mory 1994).

The Basin was initially formed through the rifting and the break-up of the Indian and Australian plates as this was the major structural formation event in Perth Basin (Crostella 1995). Following the initial rifting, subsequent deformation and deposition occurred sequentially in the basin (Mory, Haig et al. 2005). Rifting and sagging occurred along the western continental margin which caused the development of a series of normal faults that dominate the Perth Basin structure (Song and Cawood 2000).

As the drifting took place, the structure was filled by sediments which originated from the Yilgarn Craton during the late Permian through to Cretaceous periods (lasky and Mory 1994). The rate of sediment accumulation in the Perth Basin during this time frame was rapid and was controlled by the growth of the main regional faults which provided examples of a deformational environment which characterise the Western Australian continental margin prior to, and during the break-up 
(lasky and Mory 1994). The sediments were then lithified into sedimentary rocks which are characterised by sandstone, siltstone and shales (Crostella 1995).

Basin-wide erosion and uplifting occurred during the break-up, which resulted in erosion and the inversion of up to thousands of meters of sediments (Figures $2,3, \& 4$ ). The erosion and uplifting also resulted in the development of transfer faults which influenced the geometry and divided the basin into compartmentalised regions characterized as sub-basins, ridges and troughs of similar structural style reflects the present form of the geological structure (Song and Cawood 2000).

\section{Stratigraphy}

The stratigraphic unit that is most relevant to this study, the Kockatea Shale, was developed during the tectonic evolution of the basin and deposited during the early Triassic period. The Kockatea Shale forms a major source rock and local cap rock underlying reservoirs and also thought to be potential shale gas reservoir. It consist of dark shale, siltstone, and minor sandstone and limestone beds, and the unit outcrops consist of thin, red, purple or brown colour ferruginous siltstone or finegrained sandstone (Crostella 1995). Kockatea Shale deposition continued over the northern Perth Basin, with active subsidence in the Dandaragan Trough where sediment thicknesses in excess of 1000 meters were deposited (lasky and Mory 1994).

\section{The concepts for estimating pore pressure}

The formation pore pressure can be determined by direct or indirect methods (Lesso and Burgess 1986). Direct pressure measurements include the repeated formation tests (RFT), drill stems tests (DST) and Modular Formation Dynamics Tester (MDT). These measurements have been reported to provide promising results in permeable formations where the tools can be placed along the formation and allow sufficient time to reach pressure equilibrium. However, direct measurements cannot be used in shale formations because of their associated operational difficulties, e.g. the risk of differential pipe sticking and the high cost of rig time as the pore pressure in shale will need a very long time to reach equilibrium. Therefore, indirect methods that are based on compaction and porosity concepts (e.g. well log data) are used. In conjunction with the use of well log data to estimate pore pressure, the mud log data such as gas kicks, the drilling rate of penetration (ROP) and mud weight were also used to validate pore pressure estimation from well log data (Fertl 1973). The most popular prediction method for pore pressure is Eaton's method and its basic concepts are the understanding of overburden pressure, effective stress and porosity dependent parameters such as sonic transit time (Eaton 1975). As sediments are buried, the overburden stress increases and the sonic transit time decreases as a result of normal compaction trend (NCT) and its associated porosity 
reduction. As the porosity decreases, pore fluid is squeezed out by the normal increase in overburden pressure, and this will establish the normal trend of shale-porosity dependent parameters (e.g. sonic transit time decrease) and consequently normal trend of pore pressure (Draou and Osisanya 2000) (Figure 1). In many cases however, the pore fluids cannot escape and get trapped within the pore spaces due to the lack of conduits with the overlying sediments. Therefore the fluids become overpressured (Wallace 1965; Eaton 1975). This would be represented by a diversion from the normal trend of the porosity's dependent parameter (e.g. sonic transit time increase) and thus an increase in pore pressure.

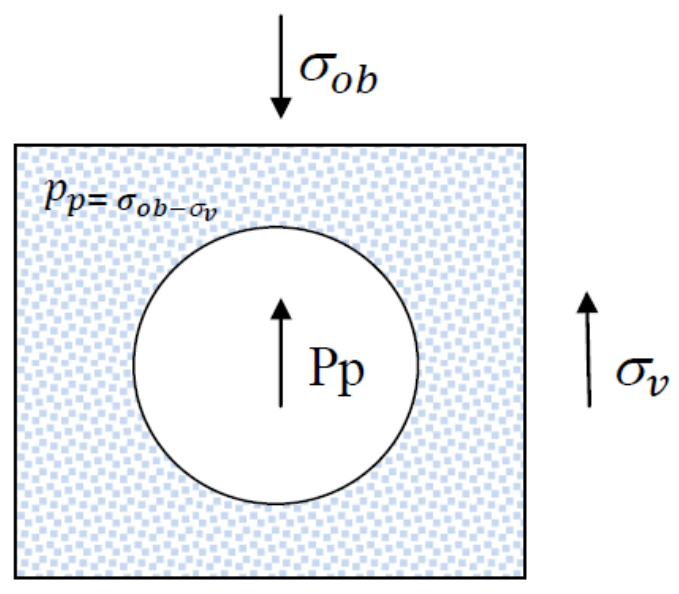

Figure 1: A simplified diagram of state of stress underground modified from (Draou and Osisanya 2000).

In this study, well log data from the Perth Basin were examined to identify evidence of overpressure in the basin and to establish a correlation between pore pressure distribution and the tectonic activities which occurred in the basin. Eaton's Method (Eaton 1975) (Eq. 1) was used to predict the pore pressure of shales using data obtained from both acoustic and resistivity logs. Relationships between shale transit time or shale resistivity verses depth were established to obtain formation hydrostatic-pressure (Foster 1966; Herring 1973). Normal Compaction Trends (NCT) in normally pressured intervals was established in clean formation, and overpressure is defined as a measure of the divergence of observed parameters from those obtained from NCT.

$$
g_{p}=g_{o b}-\left(g_{o b}-g_{n}\right)\left(\frac{\Delta t_{n}}{\Delta t_{o}}\right)^{3},,, g_{p}=g_{o b}-\left(g_{o b}-g_{n}\right)\left(\frac{R_{o}}{R_{n}}\right)^{1.2}
$$

Eaton's equations (Eaton 1975), sonic transit time (left) and resistivity (right). 
The boreholes which intersect the candidate formations have been categorized into groups according to their geographic location and as well as the intensity of the tectonic activities (Figure 2).

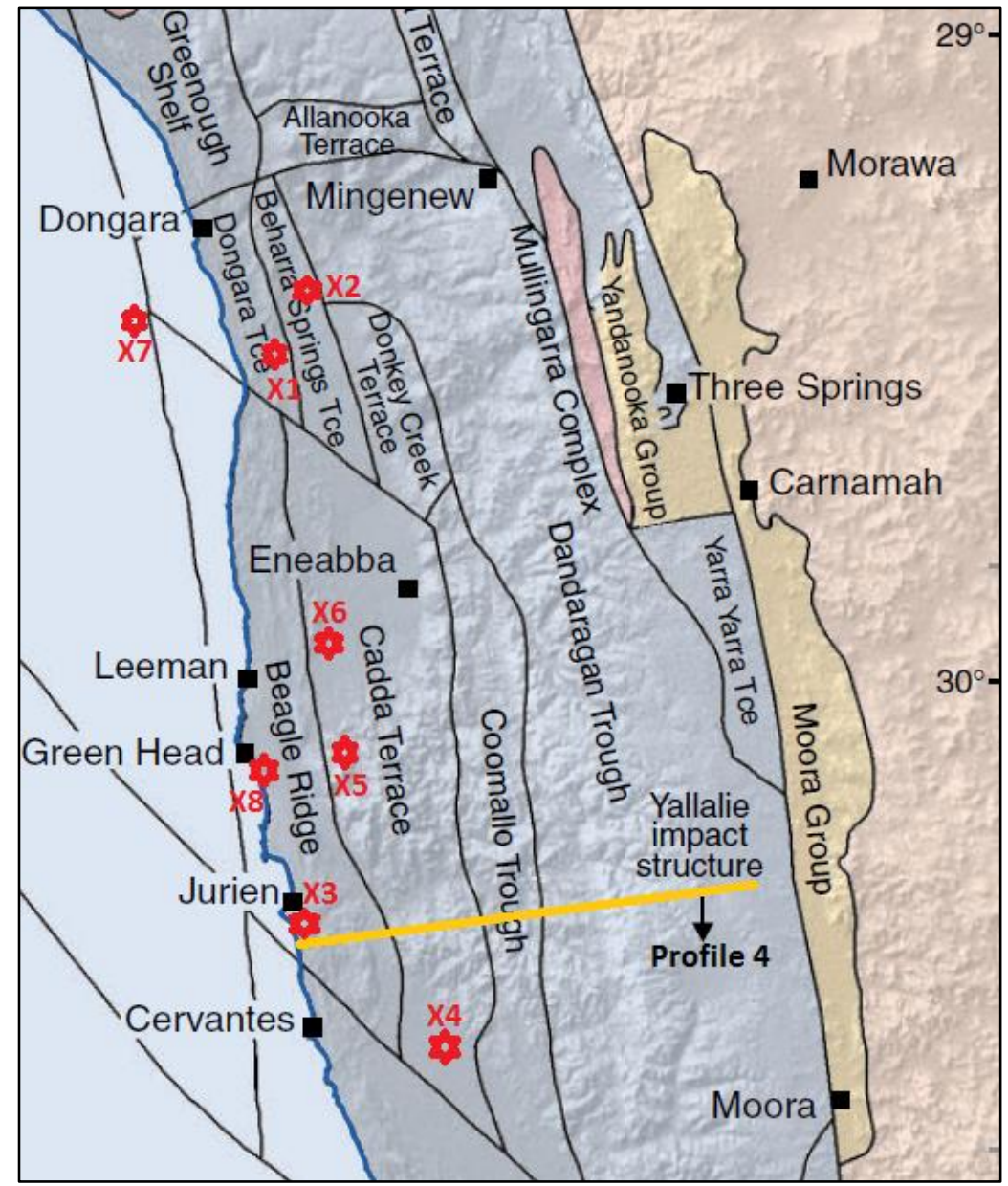

Figure 2: Tectonic divisions \& structural framework in the northern Perth Basin modified from (Mory, Haig et al. 2005)

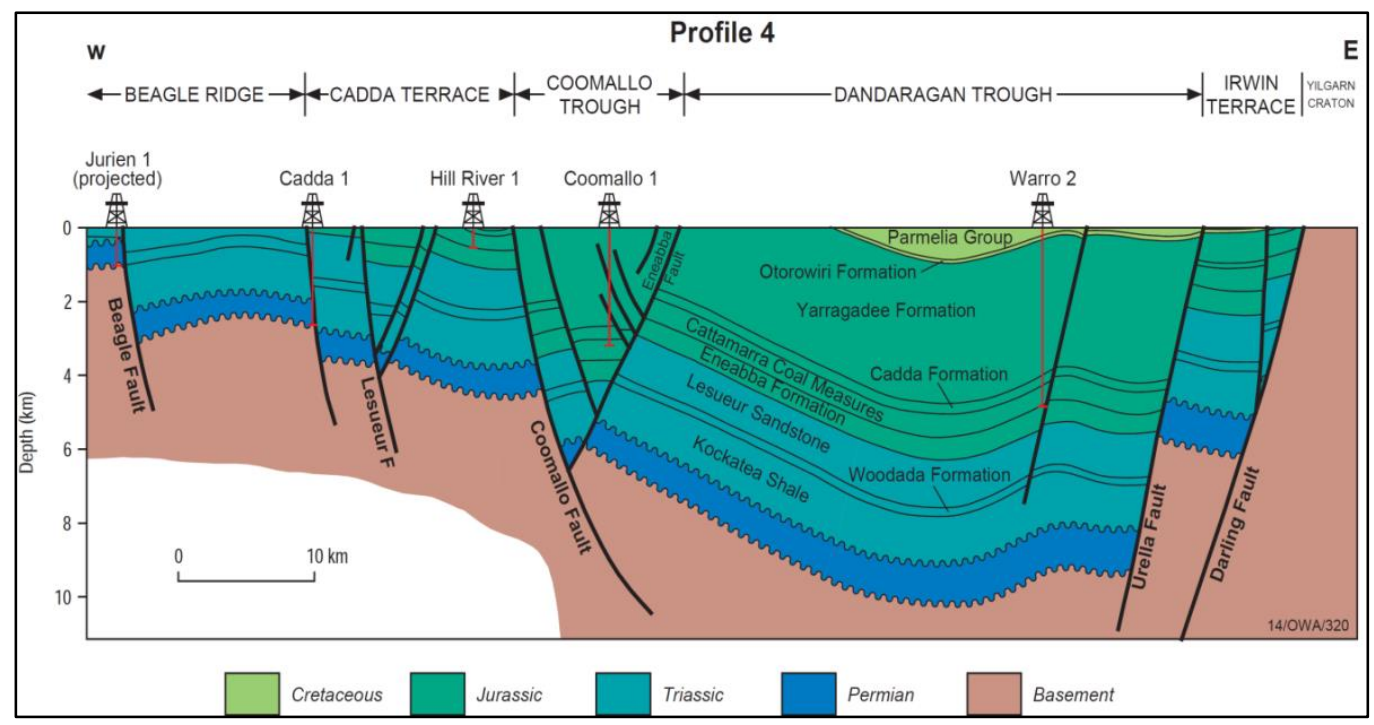

Figure 3: East-west structural section across the Dandaragan Trough and adjacent terraces (Song \& Cawood, 2000). 


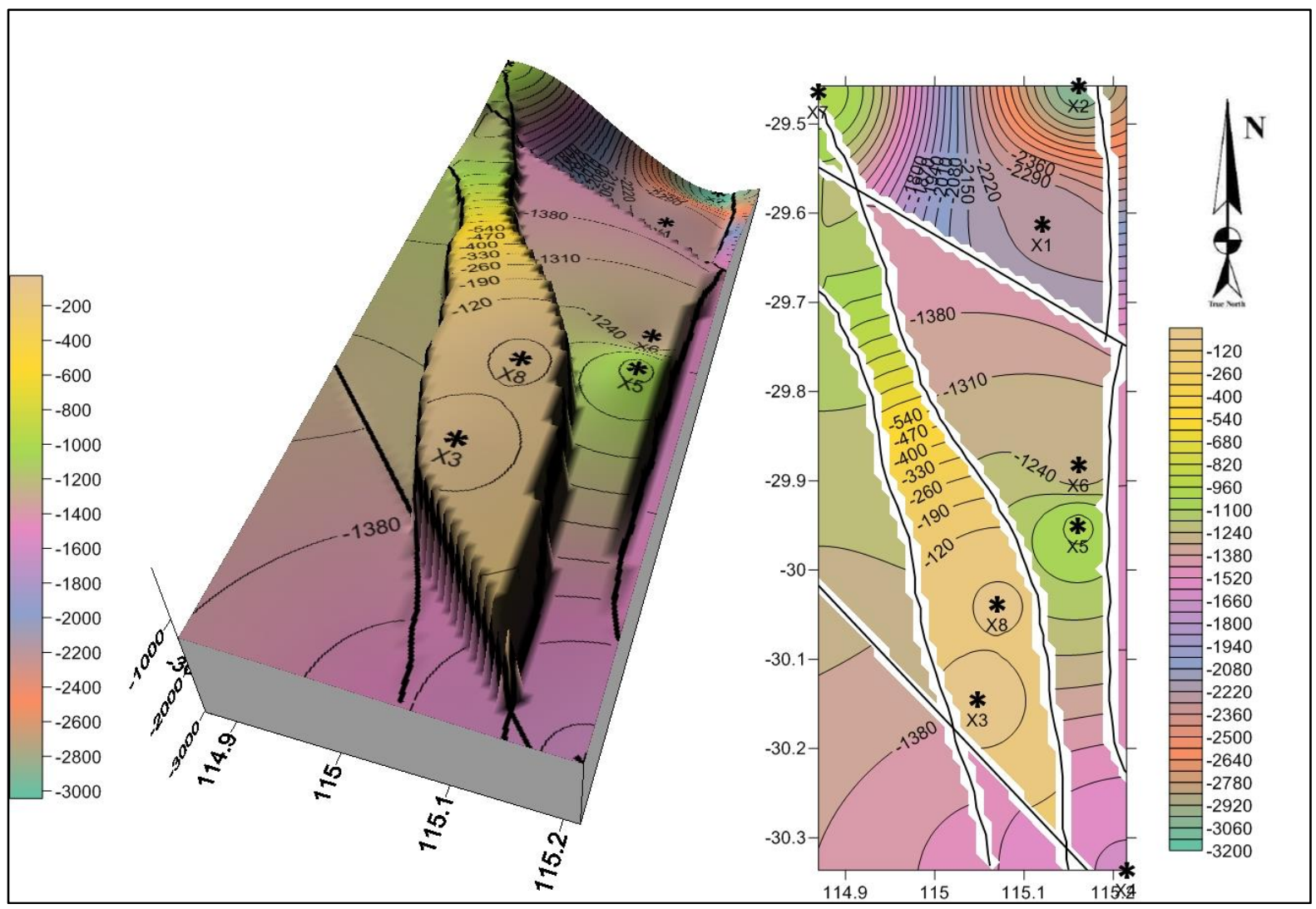

Figure 4: Depth contours of the top of Kockatea shale in the Beagle Ridge, Cadda Terrace, Beharra Spring Terrace and adjacent terraces (Perth basin).

\section{Results}

The data presented in Figure 5 is from the well X2 which is located in the northern Perth Basin. This sample well is an example for the group of wells where overpressures have been observed. Typical onshore northern Perth Basin sedimentary sections were encountered in this borehole. The average sonic transit time in the upper section of Kockatea shale is $72 \mu \mathrm{s} / \mathrm{ft}$ (Figure 5 left). The sonic transit time in this well gradually decreased as depth increased due to increasing compaction. However, in Kockatea shale, the depth-transit time trend showed an increase in sonic transit time at a depth of approximately $3320 \mathrm{~m}$ and continued to increase toward the basal section of the Kockatea shale. Shale resistivity gradually increased as the depth increased due to increasing compaction and the expulsion of pore fluid from the pores. However, in the Kockatea shale, the resistivity deviated from its normal trend at the same depth as transit time deviated and continued to decrease as the depth increased towards the basal section of the Kockatea shale. 


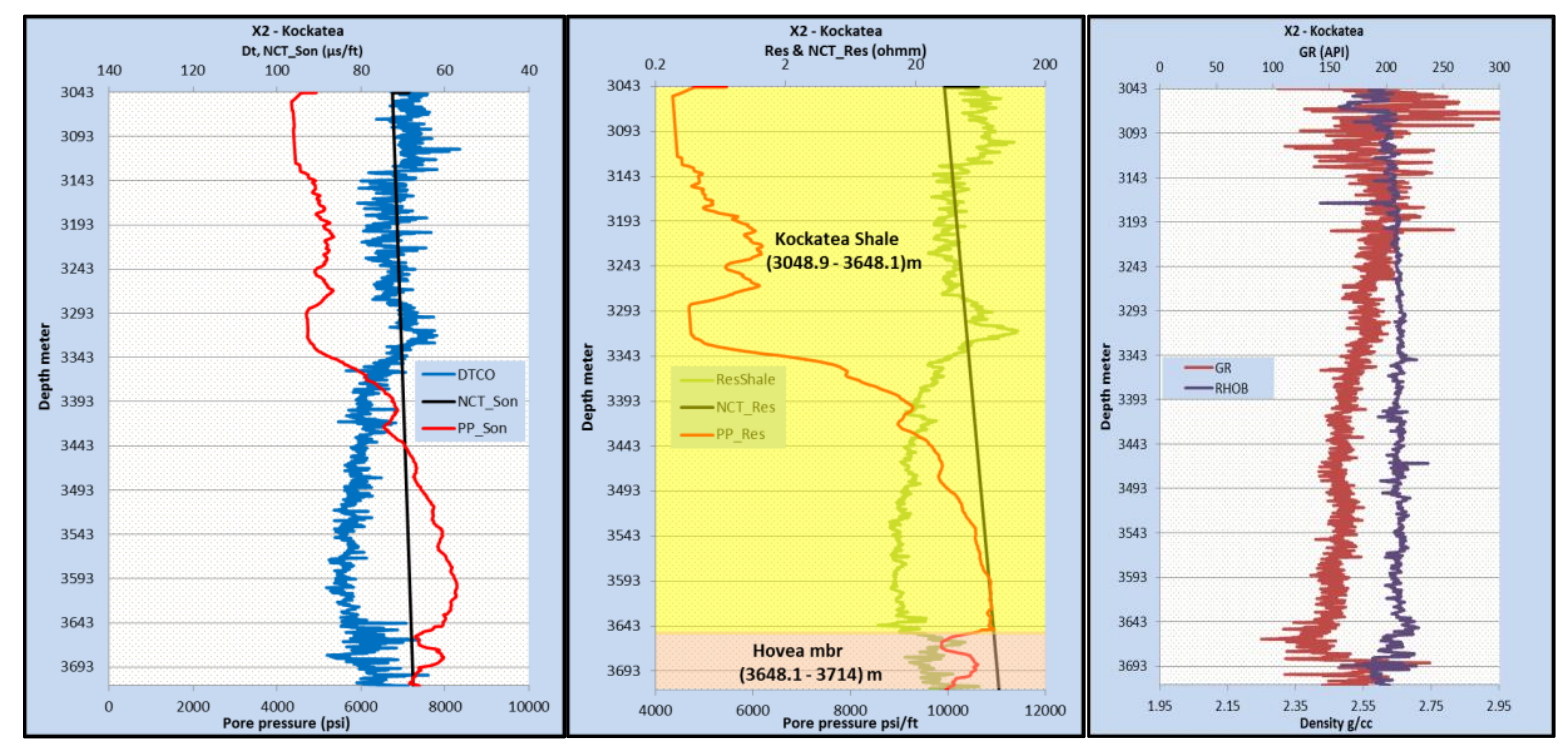

Figure 5: Pore pressure-depth plot and log data values-depth plots in Kockatea Shale in the well X2 (Perth Basin).

A review of both the drilling reports and the mud log data from the studied well showed that good gas show was recorded in the Kockatea Shale from 3295.0 m with a maximum of 3020 units compared to a background of 10 units. Below $3556 \mathrm{~m}$ the background and connection gases increased in concentration and the mud weight increased to $0.56 \mathrm{psi} / \mathrm{ft}$. In addition while there was no change in the recorded connection gases there was a significant increase in the mud losses. The rate of penetration (ROP) showed an increase in the basal section of Kockatea shale which is an additional sign of increasing in pore pressure in this section of the well (Figure 6).

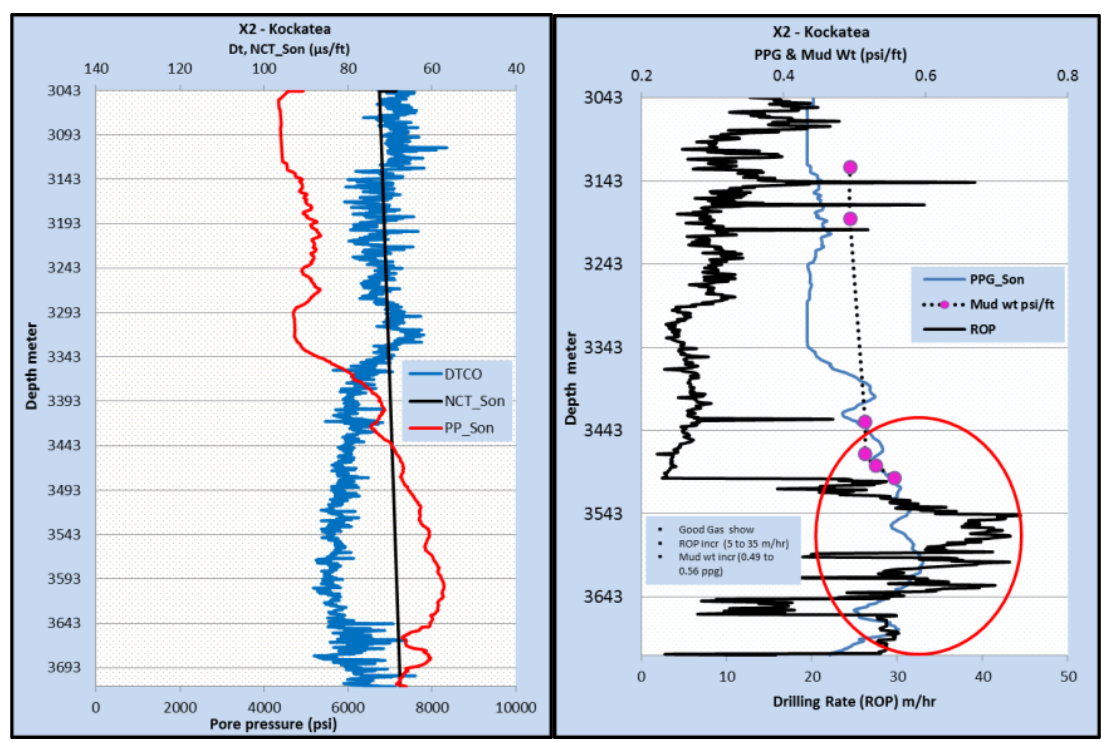

Figure 6: Pore pressure-depth plot, ROP \& Mud weight-depth plots in Kockatea Shale in the well X2 (Perth Basin). 
The well $\mathrm{X} 1$ is another borehole drilled away from any identifiable faulting within an area with a low incidence of fracturing so that a full section of the Kockatea shales could be penetrated and evaluated effectively. In reviewing the log data and the other relevant reports, the same trends of abnormality in pore pressure were observed (Figure 7).

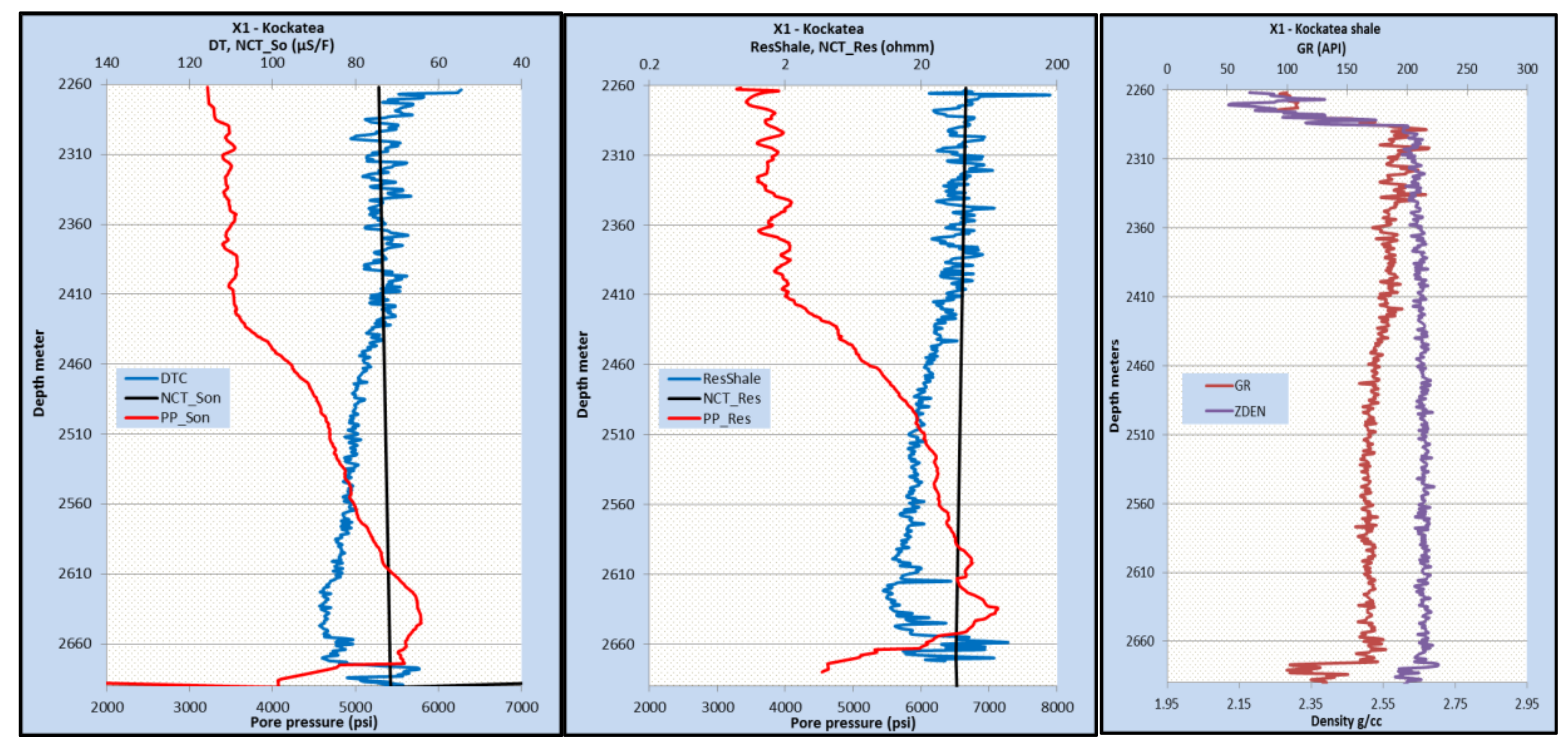

Figure 7: Pore pressure-depth plot and log data values-depth plots in Kockatea Shale in the well X1 (Perth Basin).

Similar results were found for the wells $\mathrm{X} 3, \mathrm{X} 4, \mathrm{X} 5$ and $\mathrm{X} 6$ from areas with severe uplift and erosion where normal pressures are observed (Figure 8). The well X3 was drilled in the Beagle Ridge in a very shallow structure and the well X4 was drilled in the north-central part of Perth Basin in Cadda Terrace which is adjacent to Beagle Ridge in narrow block between the Lesueur \& Cadda faults. Kockatea shale in X4 was estimated to be $915 \mathrm{~m}$ however the well went through a normal fault and the continuous diameter data clearly indicated a faulted zone in the Kockatea shale and the core cut of the top of the Kockatea indicated a faulted zone. Well X5 was also drilled in Cadda Terrace which was north east of the X3 well. The well X6 was drilled in Cadda Terrace adjacent to the Beagle Ridge. No overpressure data in the Kockatea shale were recorded at these wells (Figure 8). 

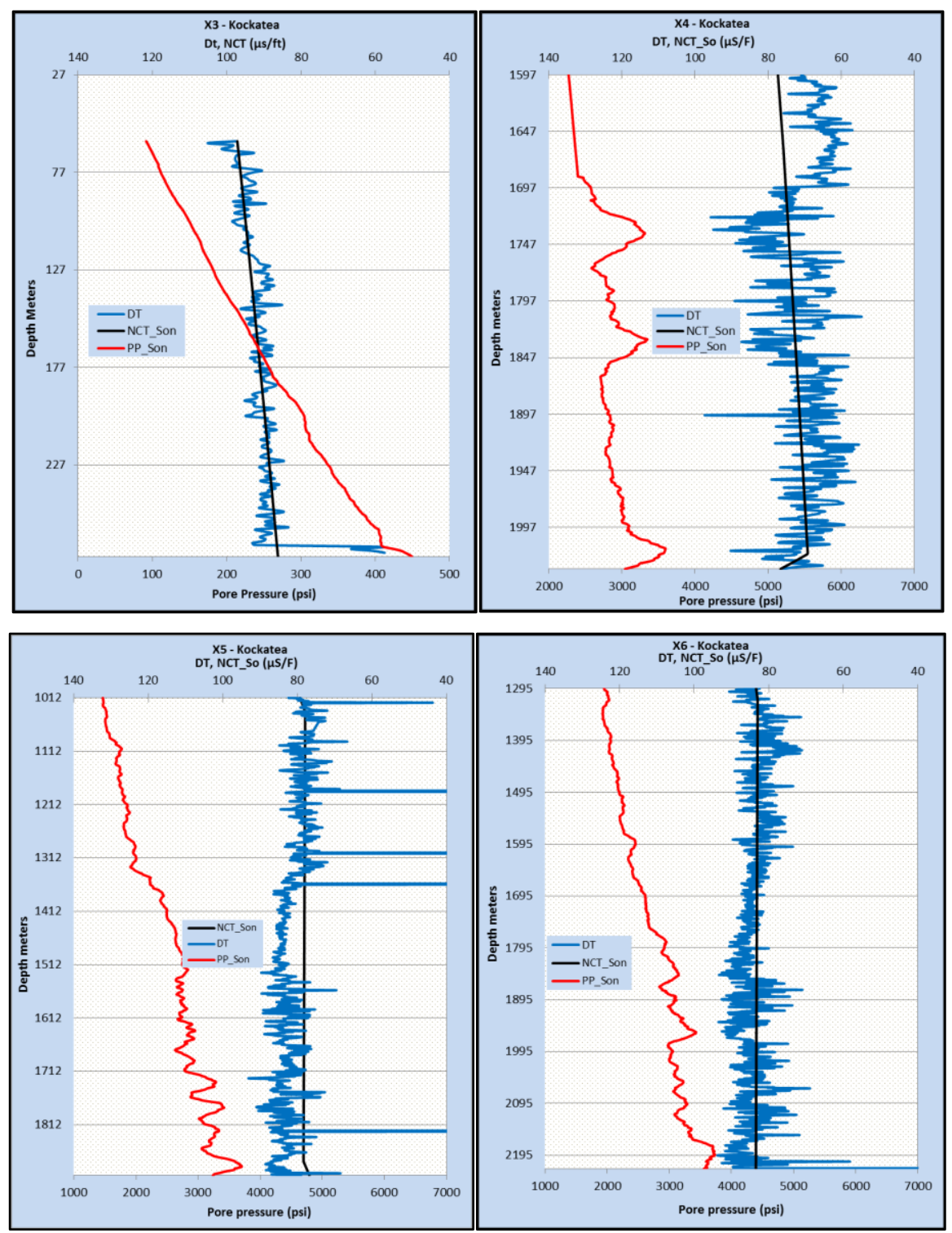

Figure 8: Pore pressure-depth plot and log data values-depth plots in Kockatea Shale in the wells X3, X5, X5 \& X6 (Perth Basin).

Well X7 was drilled offshore at the edge of northern-west part of the Beagle Ridge. No evidence of overpressure has been encountered in the Kockatea shale in this well and the pressure estimation was validated by a one point RDT pressure test conducted at the base of the Kockatea shale (Figure 9). 


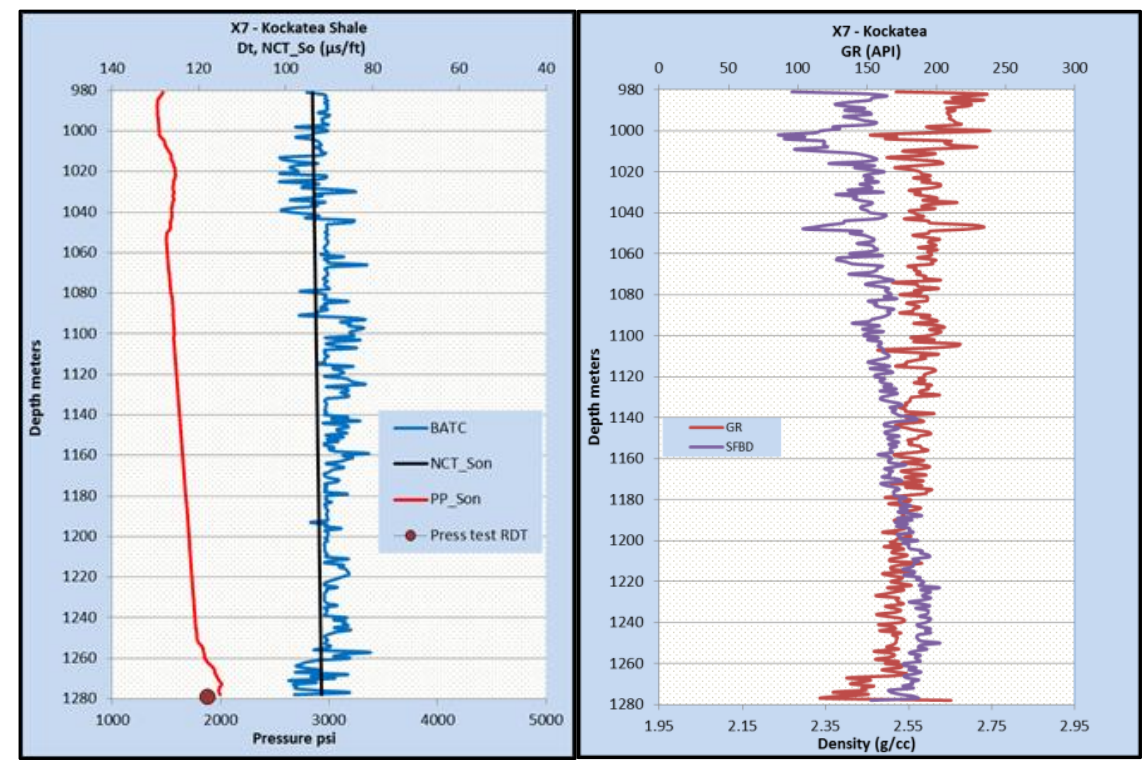

Figure 9: Pore pressure-depth plot and log data values-depth plots in Kockatea Shale in the well X7 (Perth Basin).

\section{Validation of the results}

Data obtained from wells $X 7$ and $X 2$ indicated that similar sections of similar lithology of both wells were examined to estimate pore pressure, however the results were significantly different. Well X7 was normally pressured throughout the whole section of the Kockatea shale where Gamma ray indicated approximately $185 \mathrm{API}$ and the density is $2.5 \mathrm{~g} / \mathrm{cc}$, whereas, in the well $\mathrm{X} 2$, abnormally high pressure was observed in the lower section of the Kockatea shale. The Gamma ray analysis indicated approximately $175 \mathrm{API}$ and the density of $2.6 \mathrm{~g} / \mathrm{cc}$ (Figure 10).

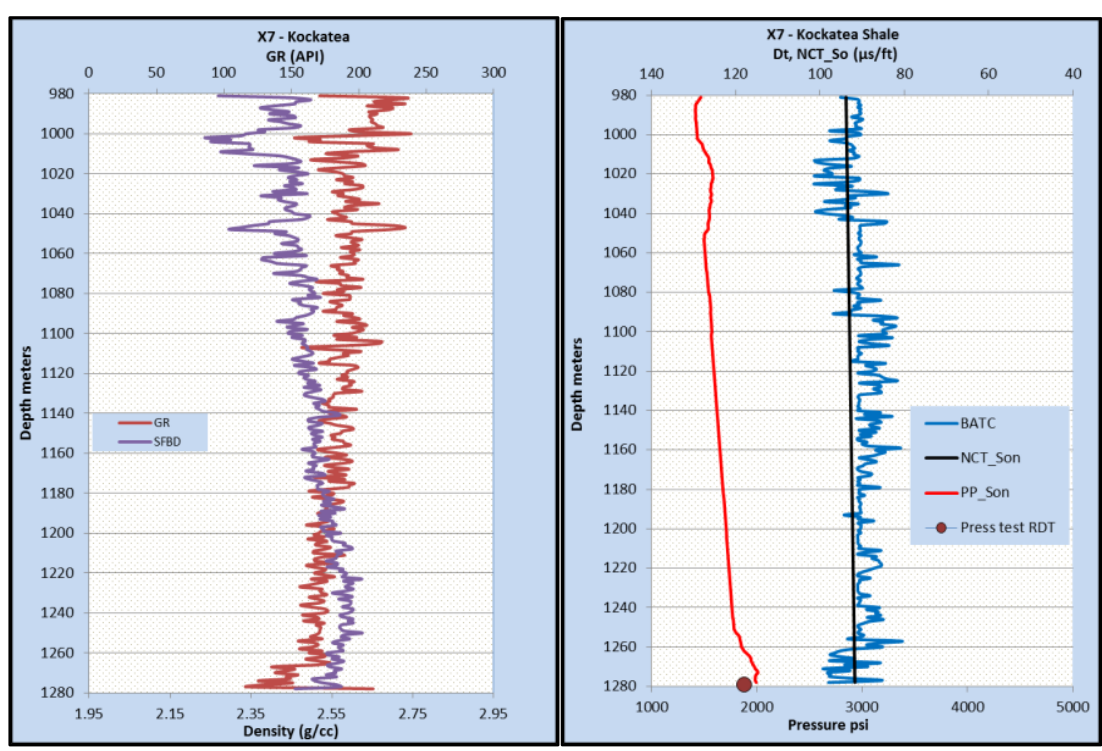




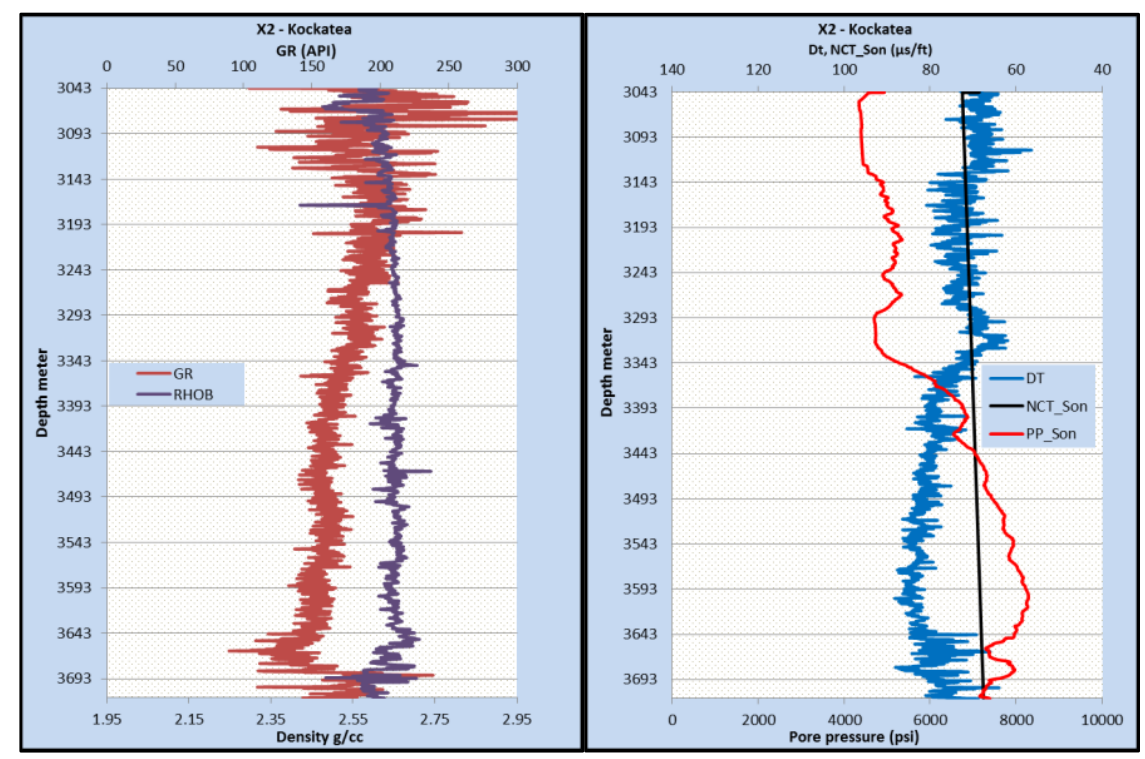

Figure 10: Comparison of Pore pressure-depth plots in Kockatea Shale between the wells X2 \& X7 (Perth Basin).

Although there is not a large number of measured pore pressure data points for shale intervals in the Perth Basin, the results validation was performed on a few measured pressure data points which were found in the well completion reports. Where there was no measured pore pressure data, a different approach was considered which was based on a comparison of the estimated pore pressure profile from log data in the charged zone to the mud weight increase in the overpressured zone. In addition, the other high pore pressure parameters such as the gas show and the increase in the drilling rate of penetration (ROP) were considered.

The measured pressures were compared to the estimated data and found to be closely matched. The first pressure point was obtained from the well $X 7$ which was drilled offshore at the edge of the northern-west part of the Beagle Ridge. No overpressure was encountered in the Kockatea shale in this well and the RDT pressure test point was on the predicted pore pressure profile at the base of the Kockatea shale (Figure 11 left). The second pressure point was obtained from the well X8 which was drilled on the Beagle Ridge in the northern part of the Perth Basin. Normal pore pressure region was observed across the Kockatea shale and DST pressure point was also on the predicted pore pressure profile (Figure 11 centre). 


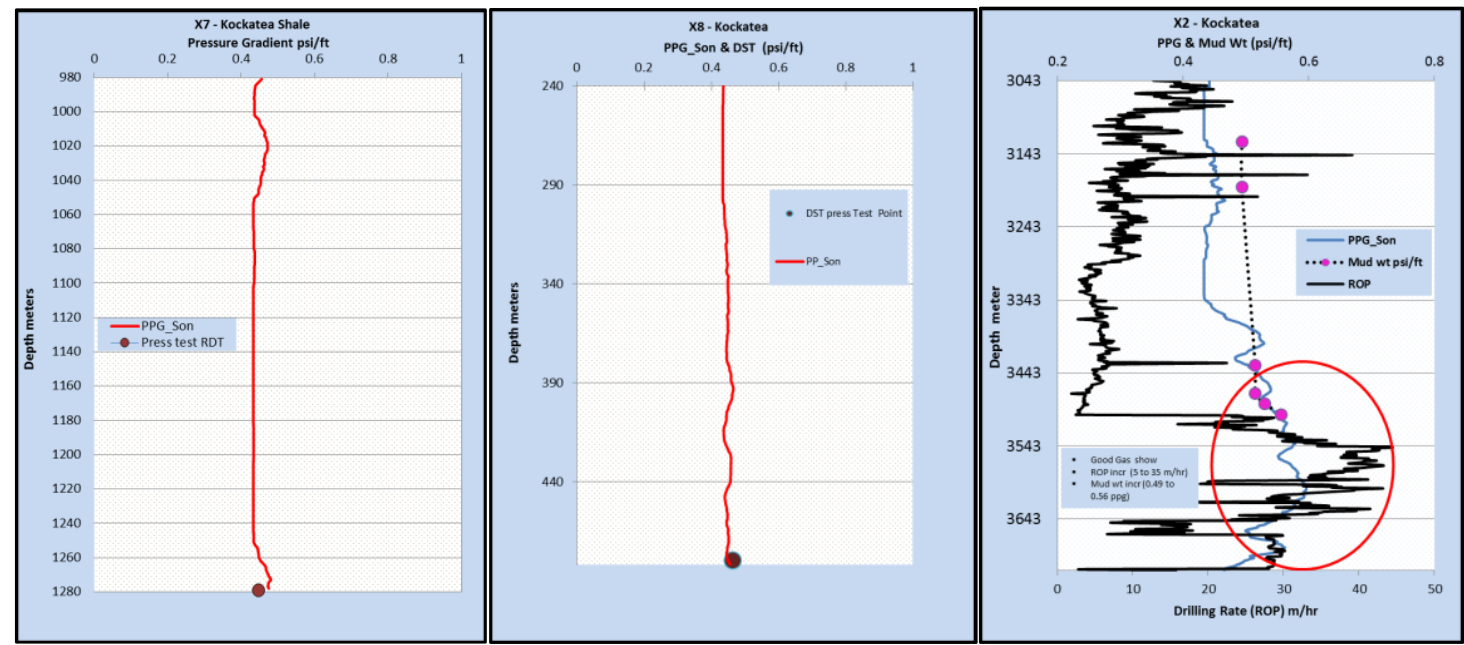

Figure 11: Predicted pore pressure vs pressure point in the wells $X 7$ (left) $X 8$ (middle) and $X 2$ (right).

As for the abnormal high pressure wells, unfortunately no measured pressure data were found in these wells, however parameters indicative of higher pressure were extracted from drilling reports including the increase in mud weight, the drilling rate of penetration (ROP) and the gas show while drilling.

As shown in the well X2 (Figure 11 right), the data indicated a continuous increase in mud weight in the overpressured section. As can be observed, the mud weight values were on the predicted pore pressure profile which in turn validated the estimated pore pressure which was obtained from the log data. Another high pore pressure indicator was an increase in drilling rate of penetration (ROP) that was observed in the overpressured section. The ROP increased from $5 \mathrm{~m} / \mathrm{hr}$ above the overpressured section to $35 \mathrm{~m} / \mathrm{hr}$ at the base of the Kockatea shale at a depth of $3556 \mathrm{~m}$ as a result of the reduction of the differential pressure between the mud weight and the formation pore pressure. In addition, there was an increase in background and connection gas concentrations across the overpressured section of Kockatea shale.

\section{Discussion}

It would appear that the uplift and erosion due to compressional tectonic activity have significantly affected the pore pressure distribution in the Perth Basin as overpressure zones existed in some regions and did not exist in some other places. Overpressures were observed in the lower section of the Kockatea shale in locations where there were less intense of tectonic activities (mainly in the deep wells). In contrast, normal pressures were observed at locations which have been rigorously uplifted and where there are severe tectonic activities (mainly in shallower wells) including the Beagle Ridge, Cadda Terrace and the terraces adjacent to the Beagle Ridge. 
The phenomenon of overpressure was observed by the diversion of the effective stress-dependent parameters from their normal trends. The top of the overpressure zones are the depths where the diversion occurred. The overpressures were confirmed by cross checking the available data which included drilling reports and mud log data.

\section{Conclusions}

- Overpressured intervals were observed in the lower sections of the Kockatea in localities where there were less intense of tectonic activities, mainly in the deep wells.

- Normal pore pressures were observed at the locations which have been rigorously uplifted and where there were severe tectonic activities, mainly in shallower wells.

- Overpressured intervals were observed in the Perth Basin where the top of Kockatea shale is buried to a deeper depth, which might imply that the number of overpressure generating mechanisms increases.

- The depth to the top of the overpressure zone was linearly related to the depth to the top of the Kockatea shale.

- Overpressure in the Perth basin was constrained within the Kockatea shale formation and more studies are required for other shale formations.

- The geographic location of the well and rapid sedimentation have resulted in the occurrence of overpressure in the well under examination.

- Tectonic activities were significant factors in pore pressure distribution in the Perth basin in many ways. Firstly, induced fractures in the shale and release the pressure through the fracture. Secondly, remove part of the formation and facilitates a re-equilibration of the pore pressure back to the normal condition.

\section{Acknowledgment}

The authors would like to thank Curtin University Shale Gas Consortium sponsors and Western Australia Department of Mine and Petroleum, Buru Energy, Carnarvon Petroleum, Norwest Energy and Woodside for the financial support and permission to publish the results of this study. 


\section{Nomenclature}

\begin{tabular}{|l|l|}
\hline Abbreviation & Log Name (unit) \\
\hline DTCO & Compressional Wave Transit time Log $(\mu \mathrm{s} / \mathrm{ft})$ \\
\hline DTC & Compressional Wave Transit time Log $(\mu \mathrm{s} / \mathrm{ft})$ \\
\hline NCT_Son & Normal Compaction Trend from Sonic Log $(\mu \mathrm{s} / \mathrm{ft})$ \\
\hline PP_Son & Pore Pressure estimated from Sonic Log $(\mathrm{psi})$ \\
\hline ResShale & Resistivity of the shale (ohmm) \\
\hline NCT_Res & Normal Compaction Trend from Resistivity Log $(\mathrm{ohmm})$ \\
\hline PP_Res & Pore Pressure estimated from Resistivity Log $(\mathrm{ohmm})$ \\
\hline GR & Gamma Ray (API) \\
\hline RHOB & Bulk Density Log $(\mathrm{g} / \mathrm{cc})$ \\
\hline PPG_Son & Pore Pressure Gradient estimated from Sonic Log $(\mathrm{psi} / \mathrm{ft})$ \\
\hline Mud wt & Mud Weight Gradient $(\mathrm{psi} / \mathrm{ft})$ \\
\hline ROP & Drilling Rate of Penetration $(\mathrm{meter} / \mathrm{hr})$ \\
\hline ZDEN & Bulk Density Log $(\mathrm{g} / \mathrm{cc})$ \\
\hline BATC & Sonic Transit time Log $(\mu \mathrm{s} / \mathrm{ft})$ \\
\hline SFBD & Smoothed Far Detector only Bulk Density $(\mathrm{g} / \mathrm{cc})$ \\
\hline$g_{p}$ & Estimated Pore Pressure Gradient $(\mathrm{psi} / \mathrm{ft})$ \\
\hline$g_{o b}$ & Overburden Pressure Gradient $(\mathrm{psi} / \mathrm{ft})$ \\
\hline$g_{n}$ & Normal Pore Pressure Gradient $(\mathrm{psi} / \mathrm{ft})$ \\
\hline$\Delta t_{n}$ & Normal Sonic Transit Time $(\mu \mathrm{s} / \mathrm{ft})$ \\
\hline$\Delta t_{o}$ & Observed Sonic Transit Time $(\mu \mathrm{s} / \mathrm{ft})$ \\
\hline$R_{n}$ & Normal Resistivity (ohmm) \\
\hline$R o$ & Observed Resistivity $(\mathrm{ohmm})$ \\
\hline & \\
\hline
\end{tabular}




\section{References}

Crostella, A. (1995). An evaluation of the hydrocarbon potential of the onshore northern Perth Basin, Western Australia, Geological Survey of Western Australia.

Draou, A. and S. O. Osisanya (2000). New Methods for Estimating of Formation Pressures and Fracture Gradients from Well Logs. SPE Annual Technical Conference and Exhibition. Dallas, Texas.

Eaton, B. (1975). The equation for geopressure prediction from well logs. Fall Meeting of the Society of Petroleum Engineers of AIME.

Eaton, B. A. (1975). The Equation for Geopressure Prediction from Well Logs. Fall Meeting of the Society of Petroleum Engineers of AIME. Dallas, Texas.

Fertl, W. (1973). Significance of shale gas as an indicator of abnormal pressures. SPE Drilling and Rock Mechanics Conference.

Foster, J. B. (1966). "Estimation of formation pressures from electrical surveys-Offshore Louisiana." Journal of Petroleum Technology 18(2): 165-171.

Herring, E. (1973). Estimating Abnormal Pressures from Log Data in the North Sea. SPE European Meeting.

lasky, R. and A. Mory (1994). "Structural and tectonic framework of the Onshore Northern Perth Basin." Exploration Geophysics 24(4): 585-592.

Lesso, J. W. G. and T. M. Burgess (1986). Pore Pressure and Porosity From MWD Measurements. SPE/IADC Drilling Conference. Dallas, Texas.

Mory, A., D. Haig, et al. (2005). "Geology of the northern Perth Basin, Western Australia -a field guide." Geological Survey of Western Australia Record 2005: 9.

Osborne, M. J. and R. E. Swarbrick (1997). "Mechanisms for generating overpressure in sedimentary basins: a reevaluation." AAPG bulletin 81(6): 1023-1041.

Song, T. and P. A. Cawood (2000). "Structural styles in the Perth Basin associated with the Mesozoic break-up of Greater India and Australia." Tectonophysics 317(1): 55-72.

Song, T. and P. A. Cawood (2000). "Structural styles in the Perth Basin associated with the Mesozoic break-up of Greater India and Australia." Tectonophysics 317(1-2): 55-72. 
Wallace, W. E. (1965). "Abnormal Subsurface Pressures Measured From Conductivity Or Resistivity Logs." The Log Analyst V(4). 